Prawo kanoniczne wymaga, aby wolna wola osoby ${ }^{4}$ zawierającej związek małżeński była pozbawiona wad. W przypadku osoby uzależnionej np. od Internetu istnieje zaburzenie sfery wolitywnej, które skutkuje wadą zgody małżeńskiej. $\mathrm{W}$ takim przypadku mamy do czynienia $\mathrm{z}$ małżeństwem zawartym nieważnie.

Zagadnienie zagrożenia, jakie wynikają z niewłaściwego używania narzędzi wirtualnych w prawie kanonicznym, jest stosunkowo nowe. Należy również podkreślić, że jest ono otwarte i podlega rozwojowi, tak jak osiągnięcia technologii, które oferują coraz więcej możliwości korzystania z rzeczywistości wirtualnej.

ks. Tomasz Białobrzeski, Warszawa

\title{
IV. ROLA RODZICÓW W PROCESIE WYCHOWANIA DZIECKA DO ODBIORU ŚRODKÓW MASOWEGO PRZEKAZU
}

Współczesne młode pokolenie w znacznym stopniu jest formowane przez środki społecznego przekazu i media elektroniczne. Statystyczny młody człowiek spędza każdego dnia wiele godzin przed telewizorem i komputerem. Jednocześnie maleje kontakt dzieci i młodzieży z rodzicami i innymi krewnymi, brakuje czasu, by rozmawiać ze sobą w sposób, który pomaga dojrzalej myśleć i wszechstronnie się rozwijać. U wielu młodych ludzi obserwuje się próbę ucieczki od rzeczywistości w świat miłych fikcji, które zapewnia wirtualna rzeczywistość. Szczególnym wyzwaniem wychowawczym stało się masowe upowszechnienie nieznanych poprzednim pokoleniom narzędzi usprawniających porozumiewanie się, zdalną współpracę i handel, rozpowszechnianie dzieł, idei, poglądów i opinii oraz ich ocenianie i komentowanie.

Przeznaczanie przez dzieci i młodzież zbyt wiele czasu na kontakt z mediami wprowadza ich w świat mitów o człowieku, wskazuje fikcyjne drogi do szczęścia, wytwarza sztuczne potrzeby w miejsce prawdziwych i nieodzownych do rozwoju. W tym kontekście, wśród pilnych zadań

4 KPK, kan. 1057: „§ 1. Małżeństwo stwarza zgoda stron między osobami prawnie do tego zdolnymi, wyrażona zgodnie z prawem, której nie może uzupełnić żadna ludzka władza. § 2. Zgoda małżeńska jest aktem woli, którym mężczyzna i kobieta w nieodwołalnym przymierzu wzajemnie się sobie oddają i przyjmują w celu stworzenia małżeństwa". 
rodzicielskiego wychowania należy wymienić kształtowanie u młodego pokolenia odpowiedzialności w korzystaniu z mediów. Wielu współczesnych rodziców potrzebuje w tym zakresie formacji, która pozwoli im na racjonalne oddziaływanie wychowawcze w tej dziedzinie.

\section{Dzieci i młodzież a media elektroniczne}

Dzieciństwo i młodość to szczególne fazy w życiu człowieka będące czasem budzenia się wielkich ideałów oraz dążenia do potwierdzenia się w twórczym działaniu, np. nauce, sporcie, zainteresowaniach, pracy. Cechą charakterystyczną młodych ludzi jest potrzeba osiągnięcia sukcesu, dlatego w tym okresie życia często podejmowane są śmiałe plany i decyzje. W dążeniu do osiągnięcia czegoś młodzież potrafi nie tyle rywalizować z innymi osobami w celu ich pokonania, lecz potrafi dążyć do „Zwyciężenia” samego siebie. Oznacza to kształtowanie zdrowych ambicji i skierowanie ku rozwojowi osobowemu. ${ }^{1}$ Młody człowiek zaczyna pełnić aktywną rolę w swoim rozwoju, ukierunkowuje własne aspiracje na realizację ideałów, które mogą dotyczyć różnych dziedzin życia. Czynniki warunkujące poziom aspiracji to najczęściej potrzeba osiągnięć w nauce, realizacja własnych zamierzeń zawodowych i rodzinnych, inteligencja i osobowość.

Oznaką dojrzewania osobowego jest również ciekawość i pragnienie poznania świata. Młodzi zaczynają z zainteresowaniem zdobywać wiedzę, chętnie wchodzą w nowe relacje międzyludzkie, lubią podróżować. Dojrzewanie jest nierzadko czasem pełnym sprzecznych dążeń - okresy otwarcia się na świat i innych ludzi przeplatają się z okresami zamykania się w sobie. Dostęp do mediów elektronicznych stwarza wiele możliwości nawiązywania znajomości i komunikowania się, ale również powoduje izolację społeczną (wirtualne relacje).

Młodzież jest otwarta na wymiar duchowy, pragnie życia w prawdzie i sprawiedliwości, a uznawane wartości stają się celem dążenia. Pojawiają się pytania egzystencjalne o sens i cel ludzkiego życia, młodzi odkrywają skończoność i ograniczoność życia fizycznego oraz doświadczają faktu przemijania życia. „Wielkie ideały okresu dojrzewania są (...) naznaczone dążeniem do transcendencji”" ${ }^{2}$ - w młodym człowieku rozwijają się wielkie

1 Zob. J. P u li kow s k i, A. U r b a n i a k, Chrześcijańskie wychowanie do miłości. Konspekty katechez dla szkół ponadpodstawowych, Wrocław 1994, s. 88.

2 J. A u g u s t y n, Wychowanie do integracji seksualnej, Kraków 1994, s. 89. 
duchowe i religijne pragnienia skupione najczęściej wokół ofiarowania innym bezinteresownej miłości. Jakże często jednak w dzisiejszych czasach młodzież nie ma możliwości poznania bogactwa swego osobowego wnętrza, gdyż proste i płytkie treści wielu przekazów medialnych promują głównie konsumpcję, przyjemność, wygodę itp. Ponadto dojrzewający ludzie potrzebują autorytetów. Poglądy uznane za prawdziwe i wartościowe oraz zgodne $\mathrm{z}$ wewnętrznym odczuciem młodych ludzi stają się dla nich ideałami. Jeżeli młodzi nie spotkają się z autorytetami reprezentującymi prawdziwe wartości, będą utożsamiać się z idolami, którzy do nich dotrą głównie przez media, najczęściej propagując pseudowartości.

Wielu spośród współczesnej młodzieży traktuje też życie jako grę, nie biorą go poważnie. Uważają, że wszystko, co ich spotyka, powinno stwarzać przyjemność (dlatego powstaje społeczeństwo konsumpcyjne), z życia trzeba korzystać, bo ono w tym momencie trwa tu i teraz. Należy chwytać dzień. Młodzi ludzie czują się wolni, są dość mobilni, natomiast przynależność do czegoś lub kogoś może być dla nich całkowicie obca. ${ }^{3}$ Razem z pojawieniem się dostępu do globalnych idei oraz wartości, znaczenie miejsca, a ściślej przestrzeni terytorialnej, zmniejsza się. W sytuacji, gdy każda osoba na świecie uzyskuje dostęp do wszystkiego, znaczenie miejsca, przestrzeni, terytorium przestaje istnieć. Następuje zniesienie związku między miejscem fizycznym a społecznym. ${ }^{4}$ Te wszystkie aspekty globalizacji znamionują epokę ponowoczesności, w której wpływ środków masowego przekazu na człowieka stał się faktem niekwestionowanym. Oddziaływanie to dostrzegalne jest we wszystkich sferach życia, a zwłaszcza w procesie wychowania, wywierając wpływ na kształtowanie postaw, poglądów czy systemu wartości człowieka.

We współczesnym świecie komputer i Internet stają się niezbędne i pojawiają się we wszystkich dziedzinach życia. Również edukacja zyskuje dzięki ogólnemu postępowi elektronicznemu. Internet to wspaniałe narzędzie do wyszukiwania informacji, szybkiego i wygodnego komunikowania się oraz nawiązywania nowych znajomości i kontaktów współpracy. Media elektroniczne stanowią aktualnie jedno z ważniejszych źródeł edukacyjnych

3 Z. M e lo s i k, Mass media, tożsamość i rekonstrukcje kultury współczesnej, Poznań 2012, s. 42.

4 J. I z a b e $1 \mathrm{~s} \mathrm{k} \mathrm{a,} \mathrm{Mass} \mathrm{media} \mathrm{i} \mathrm{multimedia-dominujaca} \mathrm{przestrzeń} w \dot{z} y c i u$ dziecka, w: E. M a r y n o w i c z - H e t k a (red.), Pedagogika społeczna, t. 2, Warszawa 2007, s. 518-533. 
dziecka, tzn. wywierają realny wpływ na jego psychikę, organizując jego doświadczenia. Jednakże ten wpływ nie zawsze jest zgodny z celami wychowawczymi formułowanymi przez dorosłych, gdyż kontakt z wirtualnym światem charakteryzuje przypadkowość i mimowolność, zaś od strony młodego odbiorcy brak umiejętności dokonywania oceny i selekcji odbieranego komunikatu. Łatwość dostępu do Sieci powoduje, że wiele osób wykorzystuje ją do nieetycznych celów lub publikuje witryny www, które nigdy nie powinny być udostępnione dzieciom. Świat wirtualny często jest pozbawiony wartości etycznych, stając się środowiskiem bardzo niebezpiecznym.

Prowadzone w ciągu ostatnich lat obserwacje dotyczące wpływu mediów na współczesnego człowieka pozwoliły ustalić, że stanowią one źródło wielu zagrożeń. ${ }^{5}$ Wpływają na intelektualną sferę funkcjonowania człowieka, wyzwalając bierną postawę odbiorcy, rodząc bezrefleksyjność i ograniczając twórcze nastawienie do świata. Powodują problemy zdrowotne, zwłaszcza w przypadku niekontrolowanego korzystania z komputera i oglądania telewizji (obniżenie sprawności ruchowej, wady wzroku i postawy, problemy psychiczne wynikające z uzależnienia). Rozluźniają więzi międzyludzkie, prowadząc w skrajnych przypadkach do całkowitej izolacji. Dają iluzję uczestnictwa i możliwość przeżywania zastępczego, bez ponoszenia skutków podejmowanych wyborów. Szczególny niepokój budzą zmiany mające miejsce w sferze emocjonalnej, jak wzrost poziomu agresji, kształtowanie postawy konsumenckiej czy formowanie fałszywej wizji siebie i świata.

Do najczęstszych źródeł zagrożeń, a zarazem przeszkód w pełniejszym korzystaniu z mediów, należą zwłaszcza: nieznajomość języka medialnego, nieetyczne posługiwanie się mediami przez nadawców oraz konsumpcjonistyczne traktowanie przekazu medialnego przez odbiorców.

Niedojrzałość psychiczna i emocjonalna dziecka, nieustabilizowany system wartości oraz brak krytycyzmu w odbiorze mediów sprawiają, że młody odbiorca nie potrafi selekcjonować, a także krytycznie oceniać ich treści. ${ }^{6} \mathrm{Ze}$ względu na brak odpowiedniej wiedzy i doświadczenia dziecko

5 J. K w i e k, Faktyczne i wyimaginowane zagrożenia wynikajace ze stosowania mediów, w: W. S t r y k o w s k i (red.), Media a edukacja, Poznań 1997, s. 73.

6 D. J u s e w i c z, Dziecko i reklama telewizyjna, w: T. A 1 e k s a n d e r (red.), Środowiska wychowawcze i edukacja dorostych $w$ dobie przemian, Kraków 2003, s. 47. 
często nie potrafi zrozumieć, co jest istotne i wartościowe, a co drugorzędne, np. odbiorca telewizji w wieku mniej więcej do 6. roku życia nie potrafi wyznaczyć granicy między fikcją a rzeczywistością. ${ }^{7}$

Nadmierne i niekontrolowane korzystanie ze środków medialnego przekazu przez młodych odbiorców nie sprzyja kształtowaniu odpowiednich wartości i poglądów, ogranicza bezpośrednie relacje międzyosobowe, potęguje postawy bierności, braku krytycyzmu i umysłowego lenistwa, osłabia rozwój wyobraźni u dziecka oraz umiejętność abstrakcyjnego myślenia, obniża zdolności kojarzenia i wnioskowania, kształtuje relatywizm poznawczy i moralny. ${ }^{8}$ Bierny i bezkrytyczny charakter korzystania z mediów może zatem budzić uzasadniony niepokój wychowawczy i rodzić potrzebę celowych oddziaływań w tym zakresie.

\section{Wychowanie do odbioru masowego przekazu medialnego}

Wychowanie jest rzeczywistością typowo ludzką, która jest włączona w złożoność ludzkiej egzystencji. Najogólniej można stwierdzić, że wychowanie jest aktem osobowym (jego podmiotem i przedmiotem jest osoba ludzka), którego celem jest kształtowanie człowieka w znaczeniu doskonalenia go we wszystkich dziedzinach jego życia i działalności, jest rozwijaniem osoby we wszystkich aspektach jej bytu. Wychowanie jest procesem, z pomocą którego człowiek jest kierowany ku swemu osobowemu spełnieniu. ${ }^{9}$

Wychowanie do odbioru masowego przekazu należy postrzegać podobnie jak przygotowanie do korzystania $\mathrm{z}$ wielu innych dóbr dostępnych człowiekowi. Posługiwanie się tymi dobrami bez należytego przygotowania często stwarza poważne zagrożenie dla człowieka, a w każdym przypadku uniemożliwia optymalne ich wykorzystanie. Wychowanie w tej dziedzinie powinno być ukierunkowane na maksymalne wykorzystanie środków społecznego przekazu do indywidualnego rozwoju oraz do dialogu

7 Z. Grze g or s k i, Dialog rodzinny - formacja i korektura wpływu masowego przekazu, w: F. A d a m s k i (red.), Wychowanie w rodzinie chrześcijańskiej, Kraków 1982, s. 476.

8 L. D y c z e w s k i, Rodzina twórca i przekazicielem kultury, Lublin 2003, s. 166-167; J. I z d e b s k a, Rodzinna edukacja medialna dziecka, w: W. S t r y k o w s k i, W. S k r z y d l e w s k i (red.), Kompetencje medialne spoleczeństwa wiedzy, Poznań 2004, s. 381.

9 A. R e g u $1 \mathrm{~s} \mathrm{k} \mathrm{a,} \mathrm{Wartość} \mathrm{czystości} \mathrm{seksualnej.} \mathrm{Analiza} \mathrm{etyczno-pedagogiczna,}$ Tychy 2007, s. 166. 
społecznego i wzajemnej współpracy wszystkich członków zbiorowości. Patrząc zaś od strony negatywnej, wychowanie powinno zabezpieczyć przed destrukcyjnym wpływem mass mediów zarówno na osobę ludzką, jak i na więzi społeczne.

$\mathrm{W}$ procesie wychowania podstawową rolę pełni rodzina stanowiąca naturalne środowisko, w którym dziecko kształtuje swoje człowieczeństwo w dojrzałą osobowość. Rodzina jako specyficzna wspólnota charakteryzuje się więzami osobowymi nie występującymi nigdzie indziej, dzięki którym ludzie otwierają się wzajemnie na siebie. Otwarcie to umożliwia przekaz wartości, poglądów, kształtowanie charakteru i osobowości, rozwijanie umiejętności i sprawności. Stanowi to ważny fundament wychowania do korzystania z mediów. „Obowiązkiem rodziców jest prawidłowe kształtowanie sumień swoich dzieci i rozwijanie w nich zmysłu krytycznego, aby uczyły się oceniać media i korzystać z nich. Dla dobra dzieci i swojego własnego rodzice muszą przyswajać sobie i praktykować umiejętności krytycznych widzów, słuchaczy i czytelników, odgrywając w swoich domach rolę wzorców rozważnego korzystania z mediów". ${ }^{10}$

Podstawowym celem rodzinnego wychowania do odbioru masowego przekazu powinno być przygotowanie dziecka do korzystania z mediów. Proces rodzinnej edukacji w tym zakresie powinien zmierzać do ukształtowania w młodych odbiorcach określonych kompetencji medialnych, które pozwolą na rozwój umiejętności selektywnego wyboru przekazów medialnych oraz krytycznego i aktywnego ich odbioru. Kompetencje medialne definiowane są jako ,wyposażenie dzisiejszego człowieka w takie umiejętności, które $\mathrm{w}$ nowoczesnym społeczeństwie pomagają mu wszechstronnie korzystać z mediów dla swojego pełnego rozwoju”. ${ }^{11}$ Głównym celem kompetencji medialnej jest „nie tyle ochrona siebie przed negatywnymi skutkami oddziaływania mediów, co przede wszystkim wszechstronne przygotowanie do coraz lepszego wykorzystywania mediów (...) dla rozwoju swojej osobowości”. ${ }^{12}$

Kształtowanie kompetencji medialnych, a także uczenie dzieci i młodzieży odpowiedzialnego wyboru oferowanych przez nie programów i treści,

10 Papieska Rada ds. Środków Społecznego Przekazu, Etyka w środkach społecznego przekazu, nr 25.

11 L. D y c z e w s k i, Konieczność kompetencji medialnej w rodzinie, w: t e n ż e (red.), Rodzina, dziecko, media, Lublin 2005, s. 345.

12 Tamże, s. 348. 
należy do podstawowych zadań w wychowaniu domowym. W realizacji tych zadań rodzice muszą „,wprowadzić reguły w korzystaniu w domu ze środków przekazu. Oznacza to zaplanowanie i zaprogramowanie posługiwania się nimi, surowe ograniczenie czasu, jaki dzieci im poświęcają, i uczynienie z rozrywki wspólnego przeżycia, zakaz używania niektórych środków przekazu i okresowe wyłączanie ich wszystkich, aby znaleźć miejsce na inne zajęcia rodzinne". ${ }^{13}$

Najlepszym zabezpieczeniem przed szkodliwym wpływem Internetu jest wiedza o nim oraz edukacja dzieci w zakresie e-bezpieczeństwa. Zainteresowanie rodziców tym, w jaki sposób dziecko korzysta z telewizji, powoduje, że sposób i zakres odbioru przekazywanych przez nią treści jest prawidłowy, jeśli chodzi o wymiar czasu korzystania z telewizji, porę odbioru programów, rodzaj i tematykę odbieranych programów oraz charakter odbioru. ${ }^{14}$ Rodzice powinni wprowadzić konkretne zasady dotyczące dostępu dziecka do telewizji. Podstawową zasadą korzystania z telewizji powinien być umiar, czyli zdolność wyboru niektórych tylko programów, oraz określenie czasu przeznaczonego na ich odbiór. Zasygnalizowane kwestie ukazują, jak niezbędny jest udział rodziców w procesie przygotowania dziecka do korzystania z mediów i kształtowania jego kompetencji medialnych.

Należy zwrócić uwagę na potrzebę odpowiedniego przygotowania rodziców do oddziaływań wychowawczych w tej dziedzinie. Chcąc wychowywać medialnie swoje dzieci, rodzice muszą najpierw zasięgnąć informacji o publikacjach, filmach, programach telewizyjnych i internetowych, które przyciągają uwagę dzieci i młodzieży, aby je zrozumieć i poprawnie ocenić. Pomocne mogą się tu okazać recenzje i oceny publikowane przez godne zaufania osoby i instytucje, a także programy wychowawcze uczące właściwego korzystania ze środków przekazu. Ważną rolę spełnia również bezpośrednia rozmowa z dziećmi o środkach przekazu, podczas której istnieje możliwość wyjaśniania, dostrzegania i oceny moralnych wartości, stanowiących podłoże danego programu, demaskowania metod manipulacji odbiorcą itd.

Rola mass mediów ma bardzo istotne znaczenie w kształtowaniu osobowości młodego człowieka. Środki masowego przekazu oddziałują na postawy dzieci i młodzieży często znacznie silniej niż wzory i modele przekazywane przez rodziców czy nauczycieli w szkołach. Rodzina wydaje

13 J a n P a w e 1 II, Orędzie na XXXVIII Światowy Dzień Środków Społecznego Przekazu, nr 5.

14 J. I z d e b s k a, Rodzinna edukacja medialna dziecka, s. 383. 
się najlepszym i najskuteczniejszym środowiskiem do wychowania do mediów. Bardzo ważna we właściwym odbiorze mediów jest sztuka dialogu, również w trakcie oglądania telewizji i surfowaniu po Internecie. Dlatego rodzina spełnia podstawową rolę w przeciwdziałaniu zagrożeniom płynącym z niekontrolowanego i nadmiernego korzystania z mediów elektronicznych. Rodzice przez swoją czujność i troskę mogą ustrzec dzieci przed scenami agresji i przemocy, gwarantując im poczucie bezpieczeństwa. Prawidłowo funkcjonująca rodzina znajduje czas na wspólne rozmowy, rozwój zainteresowań, wspólne zabawy, wycieczki, spacery.

Zadaniem rodziny i innych środowisk wychowawczych (zwłaszcza szkoły) jest przygotowanie młodego człowieka do umiejętnego korzystania ze środków społecznego przekazu, do świadomego, refleksyjnego odbioru przekazów medialnych oraz do posługiwania się mediami jako narzędziami komunikowania. Środki przekazu mogą stać się sprzymierzeńcami lub wrogami w procesie edukacji i wychowania, w zależności od tego, jak przygotujemy młodych ludzi do posługiwania się nimi.

$$
* * *
$$

Środki masowego przekazu stały się pierwszym areopagiem współczesnego świata, głównym narzędziem informacji i formacji. Z powodu rozprzestrzenienia się i wnikania w każdą dziedzinę życia stanowią środowisko ludzkiego bytowania. Wiedza o świecie i sposób myślenia o nim są w znacznym stopniu określane przez środki przekazu. Istnieją programy telewizyjne, audycje radiowe, czasopisma, książki i strony internetowe, które niosą przesłanie wychowawcze i wprowadzają młodych w świat dobra, prawdy i piękna. Jednakże istnieją też programy i treści, które nie wymagają myślenia, nie stawiają wymagań, odwołują się głównie do instynktów, popędów oraz emocji, promują mit o spontanicznej samorealizacji, o wychowaniu bez stresów czy tolerancji jako najwyższej wartości. W tej sytuacji środki masowego przekazu mogą stać się źródłem wielkiego dobra albo też wielkiego zła, mogą budować lub niszczyć, rozwijać kulturę życia lub kulturę śmierci. Dlatego potrzebne jest odpowiednie przygotowanie do korzystania mediów elektronicznych, a podstawową rolę w tym zakresie spełnia rodzina, która ma największe możliwości oddziaływania wychowawczego na młode pokolenie. 